\title{
Nakit Tutma Oranının Finansal ve Kurumsal Belirleyicileri: Borsa İstanbul Üzerine Bir İnceleme
}

\section{Fatih YİĞíT ${ }^{1}$}

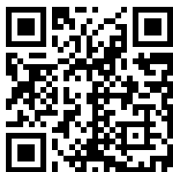

\begin{tabular}{ccc}
\hline Geliş Tarihi/ Received & Kabul Tarihi/ Accepted & Yayın Tarihi/ Published \\
16/05/2020 & $03 / 07 / 2020$ & $15 / 07 / 2020$ \\
\hline Citation/Atıf: Yiğit, F., (2020), Nakit Tutma Oranının Finansal ve Kurumsal Belirleyicileri: \\
Borsa İstanbul Üzerine Bir Inceleme, Atatürk Üniversitesi İktisadi ve İdari Bilimler Dergisi, \\
34(3): 1127-1151, DOI: 10.16951/atauniiibd.737981 \\
\hline
\end{tabular}

Öz: $\mathrm{Bu}$ çalışma, Türkiye'de şirketlerin nakit tutma oranının finansal ve kurumsal belirleyicilerini, halka açık finans dışı şirketlerin 2010 ve 2019 yılları arasındaki döneme ilişkin geniş bir veri setiyle incelemektedir. Bulgular, büyüme firsatları, kaldıraç, şirket büyüklügü, net çalışma sermayesi, nakit akışı ve sermaye harcamaları değişkenlerinin, nakit tutma oranının belirlenmesinde önemli finansal faktörler olduğunu göstermektedir. Büyüme firsatlarının pozitif ve etkisi ve sermaye harcamalarının negatif etkisi dengeleme ve finansman hiyerarşisi teorileri doğrultusunda iken şirket büyüklüğü ve nakit akışının pozitif etkileri finansman hiyerarşisi ve serbest nakit akış teorileri ile örtüşmektedir. Kaldıracın negatif etkisi ise her üç teori ile örtüşmektedir. Ancak kurumsal yönetim gölge değişkeninin pozitif işareti istatistiksel olarak anlamlı değildir. Böylece, kurumsal yönetimin nakit tutma oranını negatif etkilediğini öne süren hipotez desteklenememiștir. Bulgular, șirketlerin hedef nakit tutma oranı bulunduğunu ve hedefe doğru ayarlama yaptıklarını da göstermektedir.

Anahtar Kelimeler: Nakit Tutma Oranı, Dengesiz Panel Veri, GMM.

Financial and Institutional Determinants of Corporate Cash Holdings: An Examination on Borsa Istanbul

Abstract: This study investigates the financial and institutional determinants of corporate cash holdings in Turkey over the period of 2010 and 2019 using a broad data of non-financial public companies. The results show that growth opportunities, leverage, firm size, net working capital, cash flow, and capital expenditures are important financial factors in determining cash holdings. While positive effect of growth opportunities and negative effect of capital expenditure are in line with the expectations of the trade-off and pecking order theories, the positive effects of firm size and cash flow coincide pecking order and free cash flow theories. The negative effect of leverage corresponds to all three theories. However the positive sign of corporate governance dummy is not statistically significant. Thus, the hypothesis, which suggests that corporate governance affects the corporate cash holdings, could not be supported. The results also show that companies have target cash holdings level and adjust toward the target.

Key Words: Corporate Cash Holdings, Unbalanced Panel Data, GMM.

${ }^{1}$ Dr. Öğr. Üyesi, İstanbul Medeniyet Üniversitesi, Siyasal Bilgiler Fakültesi, İşletme Bölümü, https://orcid.org/0000-0002-1988-7962 
Nakit Tutma Oranının Finansal ve Kurumsal Belirleyicileri: Borsa İstanbul Üzerine Bir Inceleme

\section{Background}

\section{EXTENDED SUMMARY}

There are three theoretical models that explain the determinants of corporate cash holdings policy. The trade-off theory assumes that firms determine an optimal level of cash by taking into account the marginal benefit and marginal cost of cash holdings. The benefits of cash holdings are that it reduces the likelihood of financial distress, allows to pursue investment policy even if financial constraints are encountered, provides external funding and reduces costs to be incurred if assets are converted into cash. The main cost of cash holdings is the opportunity cost of capital invested in liquid assets. Secondly, the pecking order theory argues that to reduce asymmetric information and other financing costs, investments must be financed primarily by retained earnings, then by debt, and lastly by equity. According to this theory, companies do not have a target cash level. However, cash is used as a buffer between retained earnings and investment needs. The third and final one is the free cash flow theory asserts that managers tend to hold cash to increase the amount of assets under their control and gain discretion over the firm's investment decisions. Cash reduces the pressure of performance on managers and allows them to invest the projects that are more suitable for their own interests, even if it serves the interests of shareholders (Ferreira and Vilela, 2004: 295-296).

\section{Purpose}

This study aims to determine the financial and institutional factors which affect the corporate cash holdings. Although there are some studies which examine the determinants of corporate cash holdings in Turkey, these studies use either short time horizons in which the estimators couldn't yield efficient results, or data sets covering local and global crises periods, or inadequate variable sets related to firm-specific factors. In this study, we use the system GMM estimator which outperforms to other alternatives, and fairly adequate time horizon to produce instrument variables by GMM estimator. Secondly, more reliable results have been achieved by studying the period which doesn't include any local or global crises. Finally, a broad data set of the commonly used financial factors and corporate governance index dummy is used to determine the significant financial and institutional factors on corporate cash holdings.

\section{Method}

We retrieve the annual data of public firms from Compustat-Capital IQ database. Financial sector firms which have cash to meet capital requirements rather than economic reasons are excluded from the sample. While the average cash holdings of 315 firms in the sample between 2010 and 2019 is $9.97 \%$, the average cash holdings (net) is $15.03 \%$ when net assets (assets - cash and cash equivalents) is used in the denominator of the definition. It is observed that the 
cash holdings of firms fluctuates in a wide range and reaches the highest level of the last decade in 2019.

Phillips-Perron test, one of the Fisher-type unit root tests, has been used to test the stability of unbalanced panel data. According to the test result, at least one series in the panel is stationary.

\section{Findings}

Fixed effects and GMM estimators indicates that growth opportunities, leverage, firm size, net working capital, and capital expenditures have significant effects on corporate cash holdings. While positive effect of growth opportunities and negative effect of capital expenditure are in line with the expectations of the trade-off and pecking order theories, the positive effects of firm size and cash flow coincide pecking order and free cash flow theories. The negative effect of leverage corresponds to all three theories. The findings don't provide any evidence about the effect of corporate governance. System GMM estimator also reveal that firms have a target cash holdings and adjust towards this target. This finding coincides with the expectation of trade-off theory.

\section{Conclusions}

We conclude that financial factors affect the corporate cash holdings in accordance with the trade-off, pecking order, and free cash flow theories. However the findings about the institutional factors doesn't provide evidence by contrast with the expectation of free cash flow theory. Using different financial and institutional factors would help to increase the explanatory power of the model and may be reveal the effect of institutional factors. It would also contribute to the literature to use non-linear methods to discover the different structures of time periods in further studies.

\section{Giriş}

Şirketlerin olağan faaliyetlerini sürdürebilmesi için bir miktar nakit tutması gerektiği kuşkusuzdur. Ancak görünen odur ki birçok şirket olağan ihtiyaçlarını karşılayabilecek düzeyin üzerinde nakit tutmaktadır. Diğer taraftan şirketlerin nakit tutma eğilimleri zaman içinde değişmektedir. Bu değişim bazı ekonomilerde daha güçlü gözlemlenirken bazı ekonomilerde daha zayıf gerçekleşmektedir. Şirketlerin nakit tutma eğilimleri ve bunun zaman içinde değişmesi araştırmacıların ilgisini çekmiş, nakit tutma oranının belirleyicileri ve sonuçları üzerine zengin bir literatür meydana gelmiştir.

Deloitte tarafindan hazırlanan bir rapora göre dünyanın en büyük 1000 finans dışı şirketi 2,8 trilyon doları nakit olarak tutmaktadır. Sadece Amerikan şirketleri tarafından tutulan nakit toplamının 5 trilyon dolar olduğu Forbes tarafindan tahmin edilmektedir. Ancak bu durum Amerikan şirketleri ile sinırlı değildir. Japon şirketleri 2,1 trilyon dolar nakit tutmaktadır ki bu tutar, gayrisafi milli hasılanın (GSMH) \%44'üne tekabül etmektedir. Benzer şekilde Kore şirketleri GSMH'nın \%34'ü kadar olan 440 milyar doları nakit olarak tutmaktadır (Amess vd., 2015: 422). Avrupa Birliği ülkelerindeki şirketler ise 
2000 y1lı itibarıyla varlıkların \%15'i kadar, yani 303 milyar avro nakit ve nakit benzeri değer tutmaktadır (Ferreira ve Vilela, 2004: 295).

Ekonomi ve finans literatüründe şirketlerin nakit tutmasını açıklayan dört güdü belirlenmiştir. Bunlardan ilki olan işlem güdüsü, ihtiyaç duyulması halinde varlıkların nakde dönüştürülmesi için maruz kalınacak işlem maliyetlerine ilişkindir. Ölçek ekonomisinden dolayı işlem güdüsü daha zayıf olan büyük şirketlerin daha az nakit tutması beklenmektedir. İkinci olarak, sermaye piyasalarının maliyetli olması durumunda karşılaşılacak şok ile daha iyi mücadele edilmesi amacını taşıyan ihtiyat güdüsünden bahsedilmektedir. $\mathrm{Bu}$ bakış açısına göre daha riskli nakit akışına sahip ve dışsal sermayeye ulaşımı zayıf olan şirketler daha fazla nakit tutacaktır. İhtiyat güdüsü bağlamında daha güçlü yatırım firsatlarına sahip şirketler, finansal sıkıntıya daha fazla maruz kalacaklarından, daha fazla nakit tutacaktır. Üçüncü güdü, vergi güdüsü olarak adlandırılmakta olup özellikle çok uluslu şirketlerin daha fazla nakit tutması beklenmektedir. Dördüncü güdü ise Jensen (1986) tarafindan ileri sürülen vekâlet güdüsüdür. Buna göre zayıf yatıım firsatlarına sahip şirketlerin yöneticileri, hissedarlara kâr payı olarak dağıtmaktansa nakit tutmayı tercih ederler (Bates vd., 2009: 1988-1989).

$\mathrm{Bu}$ güdülerden özellikle ikisi çok daha baskın olarak hissedilmektedir. Birincisi ihtiyat güdüsüdür ki karşılaşılacak yatırım firsatlarının değerlendirilmesi için dişsal fon sağlama konusunda tereddütü olan şirketler bu güdüyle daha fazla nakit tutmaktadır. Baskın olarak hissedilen diğer güdü ise vekâlet güdüsüdür. Şirket hissedarlarının vekili konumunda olan yöneticiler nakdin sağladığı avantajlardan faydalanmak için nakit tutma eğilimindedir. Ancak bu durum hissedarların çıkarlarını zedelemektedir. Bahsedilen bu temel iki güdüden birincisi için nakit tutulması hissedarların servetini maksimize etme amacına hizmet ederken ikincisi bu amacın aleyhine sonuçlar ortaya çıkarmaktadır. $\mathrm{Bu}$ nedenledir ki ihtiyacı karşlayabilecek kadar nakit tutulmalıyken hissedarların menfaatine hizmet etmeyecek nakdin bulundurulmamas1 gerekmektedir.

Hissedarların servetini maksimize etme görevindeki şirket yönetiminin, nakit tutmanın marjinal faydasının, marjinal maliyetine eşit olduğu bir seviye belirlemesi gerekmektedir. Nakit tutmanın faydalarından birincisi fon temininde katlanılması gerekecek işlem maliyetlerinden tasarruf ve ödeme yapmak için varlıkları nakde çevirme ihtiyacının kalmamasıdır. İkinci fayda ise diğer fon kaynaklarının bulunmaması veya oldukça maliyetli olması halinde kârlı yatırım firsatlarının değerlendirilebilmesidir. Bu iki faydayı literatürde ilk kez tanımlayan Keynes (1936) birincisine işlem maliyeti güdüsü adını verirken ikincisine ihtiyat güdüsü adını vermiştir. Nakit tutmanın maliyeti ise verimsizliktir (Opler vd., 1999: 4). Verimsizlik, tutulan nakdin getiri sağlamaması yanında şirket yönetimi tarafından gereksizce kullanılmasını içermektedir. 
Piyasaların mükemmel olması durumunda yatırım firsatlarının finansmanında kullanılacak fonlar uygun fiyattan temin edilebileceğinden şirketlerin ancak olağan işlemlerini karşılayacak kadar nakde ihtiyacı olacaktır. Ancak mükemmel olmayan piyasalarda her zaman en uygun fiyattan fon temin edemeyen şirketler, karşılaşabilecekleri yatırım firsatlarını değerlendirebilmek için ihtiyat güdüsüyle nakit tutmaktadır.

Nakit tutma kararlarına etki eden şirket özelliklerinin neler olduğunu açılamaya yardımcı olabilecek üç teorik model bulunmaktadır. Bunlardan birincisi olan dengeleme teorisi, nakit tutmanın marjinal maliyeti ve marjinal faydasını dikkate alan şirketlerin optimal bir nakit tutma seviyesi belirlediklerini varsaymaktadır. Nakit tutmanın faydaları, finansal sıkıntı olasılığını düşürmesi, finansal kısıtlarla karşılaşılsa da yatırım politikasının sürdürülmesine izin vermesi, dışsal fon temini ve varlıkların nakde dönüştürülmesi durumunda katlanılacak maliyetleri düşürmesidir. Nakit tutmanın en temel maliyeti ise likit varlıklara yatırılan sermayenin firsat maliyetidir. İkinci teori Myers (1984) tarafindan ileri sürülen ve Myers ve Majluf (1984) tarafindan geliştirilen finansman hiyerarşisi teorisidir. Asimetrik bilgi ve diğer finansman maliyetlerini düşürmek için yatırımların öncelikle dağıtılmayan kârlarla, daha sonra borçla, en son ise özsermaye ile finanse edilmesi gerektiği ileri sürülmektedir. $\mathrm{Bu}$ teoriye göre şirketlerin bir hedef nakit seviyeleri bulunmamakta; ancak nakit, dağıtılmayan kârlar ile yatırım ihtiyaçları arasında bir tampon olarak kullanılmaktadır. Üçüncü ve son teori ise Jensen (1986) tarafindan öne sürülen serbest nakit akışı teorisidir. Buna göre yöneticiler, kontrolleri altındaki varlık miktarını artırmak ve şirketin yatım kararları üzerinde takdir yetkisi kazanmak için nakit tutma eğilimindedir. Nakit, performans baskısını azaltırken hissedarların çıkarlarına hizmet etmese de yöneticilerin kendi çıkarlarına en uygun projelere yatırım yapabilmelerine imkân sağlar (Ferreira ve Vilela, 2004: 295-296).

Dengeleme teorisi ile finansman hiyerarşisi teorilerini karşı1laştıran Myers (1984) finansman hiyerarşisi teorisinin de gerçek finansman kararlarının açıklanmasında en az dengeleme teorisi kadar başarılı olduğunu öne sürmektedir. Dengeleme teorisine göre şirketlerin finansman tercihleri finansal sıkıntı maliyetlerinden ciddi şekilde etkilenmekteyken finansman hiyerarşisi teorisi ters seçim probleminden dolayı önce dağıtılmayan kârlar, sonra borç ve çok gerekli olduğu durumda ise özsermaye ile finansman yoluna başvurulacağını ileri sürmektedir. Marjinal faydanın marjinal maliyeti dengelediği noktada optimum noktaya ulaşılacağını varsayan dengeleme teorisine göre şirketlerin hedef bir nakit tutma oranı bulunması gerekirken finansman hiyerarşisinde böyle bir hedef oran bulunmamaktadır. Dengeleme teorisinin temel çıkarımı nakit tutma oranının bir hedef ayarlama hareketi sergilemesi ve hedeften sapmaların aşamalı olarak ortadan kaldırılmasıdır.

Serbest nakit akışı teorisi de bir yönüyle dengelemeden bahsetmektedir. Şirket hissedarları, küçük şirkettense büyük bir şirkete sahip olmayı tercih 
ederler. $\mathrm{Bu}$ nedenle net bugünkü değeri pozitif olan tüm projelere yatırım yapılmasını ve net bugünkü değeri negatif olan tüm projelerden uzak durulmasını isterler. Ancak halka açık bir şirketin yönetimde doğrudan söz sahibi olamayan binlerce hissedarı olabilir. Şirkete istikrar sağlayan sahiplik ve kontrol ayrımı, diğer taraftan önemli bir olumsuzluk barındırır. Hissedarların çıkarlarındansa kendi çıkarlarını önceleme eğilimindeki yöneticiler için alan oluşturur (Brealey vd., 2011: 33). Serbest nakit akış1, ilgili sermaye maliyeti ile iskonto edildiğinde pozitif net bugünkü değere sahip tüm projelerin finanse edilmesi için gerekli olandan fazla nakit akışıdır. Hissedarlar ile yöneticiler arasındaki çıkar çatışması, önemli düzeyde serbest nakit akışı olması durumunda daha ciddi bir hal alacaktır (Jensen, 1986: 323). Şirketin riskini düşüreceğinden ve takdir yetkilerini artıracağından nakit tutma eğiliminde olan yöneticilerin bu eğiliminin, serbest nakit akışı azaltılarak kontrol edilebileceğini öne süren Jensen (1986), nakit tutma oranı azaltılarak yönetimsel takdirin vekâlet maliyetlerinin önüne geçilebileceğini öne sürmektedir. Vekâlet probleminin olmadığı durumda, bilgi ve finans teknolojilerindeki gelişmelerin şirketlerin nakit tutma oranlarını düşürmesi beklenmelidir. Çeşitli türev ürünlerin ortaya çıkmasıyla şirketlerin risklerden daha etkili şekilde korunması mümkün olduğundan ihtiyat güdüsünden kaynaklanan nakit tutma eğilimi düşmelidir (Bates vd., 2009: 1985-1986).

Nakit tutma oranının belirleyicileri, takip eden bölümde bir kısmından bahsedilecek olan, birçok çalıșmada incelenmiștir. Bu çalıșmada ele alınan Borsa İstanbul şirketleri üzerine de bazı çalışmalar bulunmaktadır. Ancak bu çalışmalarda ya kullanılacak tahmincinin etkin sonuçlar veremeyeceği kısa zaman aralıkları kullanılmış, ya yerel ve küresel kriz dönemlerini kapsayan ve kriz etkisinin ayrıştırılmadığ 1 veri setleri üzerinde çalışılmış, ya da şirkete özel faktörlere ilişkin daha dar değişken setleri kullanılmıştır. Bu çalışmada, diğer alternatiflerine göre üstünlüğü literatürde kabul görmüş sistem GMM tekniği kullanılmış ve sistem GMM tekniği tarafindan üretilen araç değişkenler için oldukça yeterli bir zaman aralığ 1 analiz edilmiştir. İkinci olarak yerel veya küresel krizlerin bulunmadığ 2010 'lu yıllar üzerinde çalışılarak kriz etkisinin sirayet etmediği, güvenilir sonuçlara ulaşılmıştır. Son olarak, Borsa İstanbul'da işlem gören şirketlerin finansal tablolarına dayalı olarak, literatürde sıklıkla tercih edilen faktörlerden oluşan bir veri seti yanında kurumsal yönetimin etkisini araştırmak amacıyla gölge değişken kullanılmıştır.

Çalışmanın bir sonraki bölümünde literatür incelemesi yapılarak hipotezler oluşturulacaktır. Bölüm 2'de kullanılan veri ve metodoloji tanımlanarak betimleyici istatistikler sunulacaktır. Statik ve dinamik panel veri analizleri ve ulaşılan bulgular Bölüm 3'te tartışılacaktır. Çalışmanın amacı ve bulgularının genel olarak değerlendirileceği Sonuç bölümü ile çalışma sonlandırılacaktır. 


\section{Literatür İncelemesi}

Şirketlerin nakit tutma eğilimine ilişkin olarak gelişmiş ve gelişmekte olan ülkelerden alınan örneklemlerle yapılan birçok çalışmanın yanında ülkeler arasındaki farklılıkları inceleyen çalışmalar da literatürde yer almaktadır.

Şirketlerin nakit tutma oranının belirleyicilerini ve sonuçlarını, 19711994 döneminde halka açık Amerikan şirketlerine ait verileri kullanarak inceleyen Opler vd. (1999) güçlü büyüme firsatlarına ve riskli nakit akışına sahip şirketlerin daha fazla nakit tuttuklarını tespit etmiş̧ir. Ayrıca, büyük ve kredi notu yüksek şirketler gibi sermaye piyasalarına erişimi daha rahat olanların daha düşük oranda nakit tutma eğiliminde oldukları belirlenmiştir. Amerikan sanayi şirketleri için ortalama nakit tutma oranının 1980 yılından 2006 yılına kadar iki katından daha fazla artmasının nedenlerini analiz eden Bates vd. (2009) nakit akışının daha riskli hale gelmesinin temel neden olduğunu ileri sürmektedir. Ayrıca şirketlerin yapısının zaman içinde değiştiği, daha düşük stok ve alacak düzeyine sahip olduğu ve daha fazla ARGE harcaması yapıldığı tespit edilmiştir. Nakit tutma oranlarındaki artışı açıklamada ihtiyat güdüsünün önemli bir rol oynadığına ilişkin bulgulara ulaşılırken hissedarlar ile yöneticiler arasındaki çıkar çatışmasının etkisi gözlemlenememiştir. 1970-2006 döneminde Amerikan imalat şirketlerinin ARGE harcamalarının, nakit tutma oranı üzerindeki etkisini araştıran Brown ve Petersen (2011) finansal sıkıntıya maruz kalması daha muhtemel olan şirketlerin ARGE harcamalarını karşılamak için daha çok nakit tutma eğiliminde olduğunu öne sürmektedir. Diğer taraftan finansal sıkıntıya uğrama ihtimali düşük şirketlerin ARGE harcamalarını, masraflı olan nakit dışındaki kaynaklardan fonladığı sonucuna varılmıştır. Halka açık olan ve olmayan Amerikan şirketlerinin nakit politikalarını karşılaştırmak için geniş bir veri setiyle çalışan Gao vd. (2013) halka açık olmayan şirketlerin, ortalama olarak, halka açık şirketlerin tuttuğundan $\% 50$ daha fazla nakit tuttuğunu belirlemiştir. Her bir grup için nakit politikalarının belirleyicileri incelendiğinde ise aradaki farkın halka açık şirketlerdeki daha yüksek vekâlet maliyetlerinden kaynaklandığı sonucuna varılmıştır.

Ozkan ve Ozkan (2004) İngiliz şirketlerinden oluşan örneklem üzerinde yaptıkları çalışmada nakit tutma oranının belirleyicilerini araştırmışlardır. Diğer kurumsal yönetim özellikleri arasından yönetimsel sahipliğe yoğunlaşılan çalışmada yönetimsel sahiplik ile nakit tutma arasında monoton olmayan bir iliş̧ki tespit edilmiştir. Nakit tutma oranı ile ilişkili oldukları sonucuna varılan büyüme fırsatları ve nakit akışının pozitif; likit varlıklar, kaldıraç ve banka kredilerinin ise negatif etkili oldukları tespit edilmiştir. Küçük ve orta büyüklükteki 860 İspanyol şirketinin 1996-2001 dönemindeki verisini inceleyen García-Teruel ve Martínez-Solano (2008), şirketlerin yaklaşmaya çalıştı̆̆ hedef nakit tutma seviyelerinin varlığını tespit etmiştir. Daha güçlü büyüme fırsatlarına ve daha yüksek nakit akışına sahip şirketlerin hedef seviyesinin daha yüksek olduğu sonucuna ulaşılmıştır. Çalışmanın bulguları, banka kredileri 
kullanımı ve nakit ikameleri arttığında ise nakit tutma seviyesinin düştügünü göstermektedir. Halka açık olmayan İtalyan şirketlerinden bir örneklemi inceleyen Bigelli ve Sánchez-Vidal (2012), nakit tutma oranının, dengeleme teorisinin tahminleriyle uyumlu olarak, şirket büyüklügü ve vergi oranı ile negatif, risk ile pozitif iliş̧ili olduğunu tespit etmiştir. Finansman hiyerarşisi teorisinin beklentileri ile örtüşecek şekilde nakit dönüşüm döngüsü daha uzun ve finansman açıkları daha az olan şirketlerin daha fazla nakit tuttuğu belirlenmiştir. Ayrıca nakit zengini şirketlerin daha kârlı olduğu, daha fazla kâr payı ödediği ve orta vadede daha fazla yatırım yaptığı sonucuna ulaşılmıştır.

Kurumsal gelişmenin ve kamu sahipliğinin Çin şirketlerinin nakit tutma oranlarını nasıl etkilediğini inceleyen Kusnadi vd. (2015), kurumsal gelişmenin daha ileri olduğu bölgelerdeki şirketlerin ve kamu sahipliğindeki şirketlerin daha fazla nakit tuttuğu anlaşılmıştır. Kurumsal gelişme ile nakit tutma oranı arasındaki pozitif ilişki, kamu sahipliğinde olmayan şirketlerde daha baskındır. Suudi Arabistan şirketlerinin nakit tutma oranlarının belirleyicilerini, statik ve dinamik panel veri modelleri kullanarak araştıran Guizani (2017), kaldıraç, şirket büyüklüğü, sermaye harcamaları, net çalışma sermayesi ve nakit akış oynaklığının etkilerine ilişkin istatistiksel olarak anlamlı bulgulara ulaşmıştır. Örneklem, petrokimya şirketi olanlar ve olmayanlar şeklinde ikiye ayrıldığında ise iki grup arasındaki nakit tutma oranı belirleyicileri önemli şekilde farklılaşmıştır. Petrokimya şirketi olmayanlar için sadece kaldıracın istatistiksel olarak anlamlı etkisi bulunurken petrokimya şirketlerinin nakit tutma oranlarını, kâr payı verimi, kârlılık, şirket büyüklüğü, nakit akış oynaklığg ve petrol fiyatlarından oluşan daha geniş bir değişken setinin belirlediği sonucuna varılmıştır. Jebran vd. (2019) Pakistan Borsasında işlem göre 280 şirketin 20052014 dönemine ait verisini kullanarak nakit tutma oranının belirleyicilerini kriz öncesi, kriz ve kriz sonrası döneminde incelemiştir. Elde edilen sonuçlar finansal krizin, şirketlerin nakit tutma politikalarını etkilediğini göstermektedir. Finansal krizin, şirket büyüklüğü ve kaldıracın nakit tutma oranı üzerindeki etkisini de etkilediği görülmüştür. Nakit akışı, likidite ve maddilik değişkenlerinin, nakit tutma oranının önemli belirleyicilerinden olduğu da tespit edilmiştir.

Şirketlerin nakit tutma seviyelerini açıklayabilecek faktörleri analiz eden Uyar ve Kuzey (2014), 1997-2014 döneminde Borsa İstanbul'da işlem gören finans dış1 şirketlerin verisini kullanmıştır. Türk şirketlerinin ortalama olarak $\% 9,1$ oranında nakit ve nakit benzeri değerler tuttuğunun işaret edildiği çalışmada, bir önceki yılın nakit tutma oranının pozitif etkili olduğu tespit edilerek şirketlerin hedef nakit seviyeleri bulunduğu öne sürülmüştür. Nakit akış1 ve büyüme firsatlarının, nakit seviyesi üzerinde pozitif etkili olduğu bulunurken sermaye harcamaları, nakit ikamesi olarak kullanılabilecek likit varlıklar, varlıkların maddiliği, finansal borç oranı ve kaldıracın, nakit seviyesi üzerinde negatif etkili olduğu tespit edilmiştir. Yönetim kurulunun bazı özelliklerini, kurumsal yönetim kalitesinin göstergesi olarak kullanan Abdioğlu 
(2016) BIST100 endeksinde yer alan şirketlerin 2009-2013 dönemindeki verisini analiz ederek zayıf kurumsal yönetimin göstergesi olan birbirinin yönetim kurulunda üye yöneticiler dışında nakit tutma oranı üzerinde etkili başka bir faktör tespit edememiştir. Sadece bu değişken ile elde edilen sonuca göre zayıf kurumsal yönetim kalitesinin daha yüksek nakit tutma oranına neden olduğu sonucuna varılmıştır. Borsa İstanbul'da işlem gören reel sektör şirketlerinin nakit ve net nakit bulundurma düzeylerini 2005-2015 dönemine ilişkin veriyi kullanarak inceleyen Kutlu Furtuna (2017) nakit bulundurma düzeylerinin, dengeleme teorisine uygun olarak bir hedefe doğru hareket ettiği sonucuna ulaşmıştır.

Amerika, Almanya ve Japonya'dan sanayi şirketlerini inceleyen Pinkowitz ve Williamson (2001), Japon şirketlerinin daha fazla nakit tuttuğunu tespit etmiştir. Bu durumun Japon bankalarının tekel gücünden kaynaklandığı sonucuna varılmıştır. Bankaların gücü zayıfladığında Japon şirketlerinin nakit seviyelerinin Amerikan şirketlerinin seviyesine düştüğü gözlemlenmiştir. Avrupa Birliği ülkelerindeki şirketlerin nakit tutma davranışlarını belirleyen faktörleri inceleyen Ferreira ve Vilela (2004) yatırım firsatlarının ve nakit akışının pozitif, likidite, kaldıraç ve şirket büyüklüğünün negatif etkili olduğunu tespit etmiştir. Banka kredileri ile nakit tutma oranı arasındaki negatif ilişkinin, ihtiyat nedeniyle şirketler tarafindan fazla nakit tutulmasına bankalarca izin verilmediğinin göstergesi olduğu ileri sürülmektedir. Diğer taraftan yatırımcının daha iyi korunduğu ülkelerde nakit tutma oranının düşük olduğu görülmüştür. Sermaye piyasalarının gelişiminin de nakit tutma oranı üzerinde negatif etkisi gözlemlenmiştir.

Gelişmekte olan ülkelerde nakit tutma oranlarını araştıran Al-Najjar (2013), özellikle sermaye yapısının ve kâr payı politikasının, BRIC ülkelerindeki (Brezilya, Rusya, Hindistan, Çin) nakit tutma oranları üzerindeki etkisini inceleyerek Amerika ve İngiltere örneklemleriyle karşılaştırmıştır. Sermaye yapısı, kâr payı politikası ve şirket büyüklügünün, nakit tutma oranının önemli belirleyicileri olduğunun yanında gelişmiş ve gelişmekte olan ülkelerdeki şirketlerin benzer davranışlar sergilediği sonucuna ulaşılmıştır. Gelişmekte olan 20 ülkeden 7319 halka açık ve 9453 halka açık olmayan şirketin 2001-2010 dönemine ilişkin verisini analiz eden Hall vd. (2014), halka açı olmayan şirketlerin nakit tutma eğiliminin halka açık olanlardan daha fazla olduğu, piyasa odaklı ülkelerde daha yüksek oranda nakit tutulduğu ve her iki gruptaki şirketlerin nakit tutma oranlarının belirleyicilerinin benzer olduğu sonucuna varmıştır. Ekonomik politika belirsizliğinin BRIC ülkeleri şirketlerinin nakit tutma kararlarına etkisini inceleyen Demir ve Ersan (2017), belirsizlik arttıkça şirketlerin daha fazla nakit tutmayı tercih ettiklerini gözlemlemiştir. Nakit tutma oranının, Rusya dışındaki üç ülkede büyüme fırsatlarından pozitif, Hindistan haricinde üç ülkede şirket büyüklügüunden pozitif, kaldıraç, kârlılık ve kâr payı ödemesinden ise tüm ülkelerde pozitif etkilendiği bulunmuştur. 
Nakit Tutma Oraninin Finansal ve Kurumsal Belirleyicileri: Borsa İstanbul Üzerine Bir Inceleme

45 ülkeden 11000'den fazla şirketin verisini kullanan Dittmar vd. (2003) hissedarların haklarının iyi şekilde korunmadığı ülkelerdeki şirketlerin, hissedar haklarının daha iyi korunduğu ülkelerdeki şirketlerin iki katına kadar daha fazla nakit tuttukları bulunmuştur. Hissedar koruması zayıf olduğunda yatırım firsatları gibi nakit tutma ihtiyacından kaynaklanan faktörlerin daha önemli ve asimetrik bilginin daha az önemli hale geldiği tespit edilmiştir. Vekâlet maliyetlerinin önemi ile tutarlı olarak, fonlara ulaşımı daha kolay olan şirketlerin daha fazla nakit tuttuğu sonucuna varılmıştır. Orlova ve Sun (2018) özellikle kurumsal yönetim ve yatırımcı hakları koruması olmak üzere kurumsal etkenlerin, nakit tutma oranının hedeften sapmasını ve ayarlama hızını etkileyip etkilemediğini araştırmıştır. Gelişmiş ve gelişmekte olan ülkelerdeki şirketlere ait geniş bir veri setiyle yapılan çalışmada kurumsal yönetimin de dâhil olduğu kurumsal belirleyicilerin, nakit tutma oranını ve hedef nakit tutma oranına doğru ayarlama hızını etkilediği görülmüştür.

\subsection{Hipotezlerin Oluşturulması}

Dengeleme teorisine göre, yatırım firsatlarına sahip bir şirketin gerektiğinde fon bulamaması, yatırımların yapılamaması veya yüksek maliyetli fonlar nedeniyle firsat maliyetine neden olacaktır. Ayrıca yatırım firsatlarına sahip şirketlerin daha yüksek finansal sıkıntı maliyetine maruz kalacağı beklenmektedir. $\mathrm{Bu}$ nedenlerden dolayı güçlü yatırım firsatlarına sahip şirketlerin daha fazla nakit tutması beklenir. Yatırım firsatlarına sahip şirketlerin öncelikle içsel kaynaklardan fon sağlamasının esas olduğu finansman hiyerarşisi teorisi de güçlü yatırım firsatlarına sahip şirketlerin daha fazla nakit tutmasını beklemektedir. Diğer taraftan, serbest nakit akışı teorisine göre zayıf yatırım firsatlarına sahip şirketlerin yöneticilerince, net bugünkü değeri negatif olsa dahi, kendi takdir yetkilerini güçlendirecek projelere yatırım yapılması için fazla nakit tutulacağından büyüme firsatları ile nakit tutma oranı arasında negatif bir ilişki olacaktır. Alternatif hipotez, dengeleme ve finansman hiyerarşisi teorilerinin beklentileri doğrultusunda oluşturulmuştur.

H1. Nakit tutma oranı ile büyüme firsatları arasında pozitif ilişki vardır.

Dengeleme teorisi, finansal sıkıntı olasılığını artıracağından yüksek kaldıraçlı şirketlerin bu olumsuzluğu gidermek için daha fazla nakit tutmasını beklemektedir. Kaldıraç, şirket borç temin etme kabiliyetinin bir göstergesi olarak kabul edilecek olursa yüksek kaldıraçlı şirketlerin daha az nakit tutması beklenecektir. Finansman hiyerarşisi teorisinde ise yatımlar için gerekli fonlar dağıtılmayan kârlarla karşılanamadığında borç oranı artacaktır. Bu durumda nakit de yatırıma sevk edileceğinden nakit tutma ile kaldıraç arasında negatif bir ilişki beklenmektedir. Serbest nakit akış teorisi, düşük kaldıraçlı şirketler daha az takip edileceğinden yönetimsel takdirin güçleneceğini ve daha fazla nakit tutulacağını ileri sürmektedir. Her üç teorinin ortak beklentileri doğrultusunda alternatif hipotez oluşturulmuştur.

H2. Nakit tutma oranı ile kaldıraç arasında negatif iliş̧ki vardır. 
Nakit yönetiminde ölçek ekonomisi bulunduğundan hareketle dengeleme teorisince büyük şirketlerin daha az nakit tutması beklenir. Fon temini daha maliyetli olan küçük şirketlerin daha fazla nakit tutması gerekmektedir. Ayrıca faaliyetlerini farklı alanlara yönlendirmiş büyük şirketlerin finansal sıkıntıya uğrama olasılığ daha düşüktür. Bu nedenlerle şirket büyüklüğü ile nakit tutma arasında negatif bir ilişki beklenmektedir. Ancak büyük şirketlerin daha başarılı olduğunu varsayan finansman hiyerarşisi teorisi, şirket büyüklüğü ile nakit tutma arasında pozitif ilişki beklemektedir. Serbest nakit akış teorisi ise daha geniş ortaklık dağılımına sahip büyük şirketlerde yönetimsel takdirin güçleneceğini ileri sürmektedir. Yönetimsel takdirin güçlenmesiyle nakit tutma oranının artacağı beklendiğinden şirket büyüklüğü ile nakit tutma arasında pozitif ilişki ortaya çıkacaktır. Alternatif hipotez, finansman hiyerarşisi ve serbest nakit akış teorilerinin beklentileri doğrultusunda oluşturulmuştur.

H3. Nakit tutma oranı ile şirket büyüklügü̈ arasında pozitif ilişki vardır.

Bates vd. (2009) net çalışma sermayesi, nakit akışı, sermaye harcamaları ve ARGE giderlerinin nakit tutma oranını etkileyen en önemli faktörler olduğunu ileri sürmektedir. Dengeleme teorisi, nakdin ikamesi olduğunu ve gerektiğinde nakde dönüştürülebileceğini varsaydığı likit varlıklara sahip şirketlerin daha düşük düzeyde nakit tutmasını beklemektedir. Stok ve alacaklar gibi hızlı şekilde nakde dönüştürülebilecek varlıklara sahip şirketler daha az nakit tutma eğiliminde olacaklardır. Bu nedenle nakit ve nakit benzeri değerler haricindeki net çalışma sermayesi yüksek olan şirketlerin daha düşük nakit tutma oranına sahip olmaları beklenmektedir. vardir.

H4. Nakit tutma oranı ile net çalışma sermayesi arasında negatif ilişki

Nakit akışını, likit bir kaynak sağladığından, nakit gibi düşünen dengeleme teorisi, nakit akışı ile nakit tutma arasında negatif ilişki beklemektedir. Dengeleme teorisine göre yüksek nakit akışına sahip şirketler, düşük finansal sıkıntı maliyetlerine maruz kalacağından ihtiyaç halinde piyasadan uygun koşullarda nakit sağlayabilecektir. Finansman hiyerarşisi teorisi de nakit akışı yüksek şirketlerin daha fazla nakit tutacaklarını öngördüğünden aradaki ilişkinin pozitif olmasını beklemektedir. Nakit akışı yüksek şirketlerde yöneticilerin takdir yetkilerini güçlendirme çabasında olacağını ileri süren serbest nakit akışı teorisine göre de nakit akışı yüksek şirketler daha fazla nakit tutacaktır. Alternatif hipotez, finansman hiyerarşisi ve serbest nakit akış teorilerinin beklentileri doğrultusunda oluşturulmuştur.

H5. Nakit tutma oranı ile nakit akışı arasında pozitif ilişki vardır.

Dengeleme teorisine göre, sermaye harcamaları, teminat olarak kullanılabilecek varlıklar yaratacağından borç kapasitesini artıracak ve nakit tutma oranını düşürecektir. Diğer taraftan, finansal sıkıntı maliyetlerinin veya yatırım fırsatlarının göstergesi olarak kullanılacak olursa yatırım harcamaları ile nakit tutma oranının pozitif ilişkili olması beklenir. Finansman hiyerarşisi teorisi, yatırım kararlarının şirketin nakit seviyesini düşüreceğini 
Nakit Tutma Oraninin Finansal ve Kurumsal Belirleyicileri: Borsa İstanbul Üzerine Bir Inceleme

öngörmektedir. Dengeleme ve finansman hiyerarşisi teorilerinin öngörüleri doğrultusunda aşağıdaki alternatif hipotez oluşturulmuştur.

H6. Nakit tutma oranı ile sermaye harcamaları arasında negatif ilişki vardir.

Kurumsal yönetimin, şirketlerin nakit tutma düzeyleri üzerindeki etkisi üzerine yapılan çalışmalar da literatürde önemli bir yer tutmaktadır. Jensen (1986) tarafindan ortaya konan serbest nakit akışı teorisine göre hissedarlar ile yöneticiler arasında çıkar çatışması bulunmaktadır. Hissedarların zayıf şekilde korunduğu şirketlerde yöneticilerin kendi takdirlerindeki nakdi artırma eğiliminde olacakları beklenmektedir. Kurumsal yönetimin güçlü olduğu şirketlerde ise yöneticilerin gerekli olandan fazla nakit tutamamaları beklenmektedir.

H7. Nakit tutma oranı ile kurumsal yönetim arasında negatif ilişki vardır.

\section{Veri ve Metodoloji}

Hipotezlerin test edilmesi amacıyla aşağıdaki panel regresyon modeli oluşturulmuştur. Bu model ile büyüme firsatları (PDO), kaldıraç (KAL), şirket büyüklüğü (BÜY), net çalışma sermayesi (NÇS), nakit akışı (NAK), sermaye harcamaları (SHAR), kurumsal yönetim (KYÖN) değişkenlerinin nakit tutma oranı (NTO) üzerindeki etkileri bir önceki bölümde oluşturulan hipotezler çerçevesinde incelenmektedir.

$$
\begin{gathered}
N T O_{i t}=\alpha_{i}+\gamma_{0}+\gamma_{1} P D O_{i, t}+\gamma_{2} K A L_{i, t}+\gamma_{3} B \ddot{U} Y_{i, t}+\gamma_{4} N C ̧ S_{i, t}+\gamma_{5} N A K_{i, t} \\
+\gamma_{6} S_{H A R_{i, t}}+\gamma_{1} K Y O ̈ N_{i, t}+\varepsilon_{i t}
\end{gathered}
$$

Borsa İstanbul'da 2010 ile 2019 yılları arasında işlem gören şirketlere yıllık veri, Compustat-Capital IQ veri tabanından temin edilmiştir. Ekonomik nedenlerden değil de sermaye gerekliliklerini karşılamak için nakit bulunduran finans sektörü şirketleri örneklemden çıkarılmıştır. Aşağıdaki tabloda tanımlamaları sunulan değişkenlerden en az birine ait veri içermeyen gözlemler de örneklemden çıkarılmıştır. Nakit tutma oranı, nakit ve benzeri değerlerin varlıklara bölünmesiyle bulunmuştur. Büyüme firsatlarının göstergesi olan piyasa / defter oranı, varlıklardan özsermayenin defter değeri çıkarılıp özsermayenin piyasa değeri eklenerek hesaplanan piyasa değerinin varlıklara bölünmesiyle elde edilmiştir. Kaldıraç oranına kısa ve uzun vadeli yükümlülüklerin tamamının varlıklara bölünmesiyle ulaşılmıştır. TÜFE kullanılarak 2019 fiyatlarına dönüştürülen varlıkların doğal logaritması alınarak şirket büyüklügü değişkeni hesaplanmıştır. Net çalışma sermayesi, nakit ve nakit benzeri değerler hariç varlıklardan kısa vadeli yükümlülüklerin çıkarılıp varlıklara bölünmesiyle bulunmuştur. Nakit akışı, vergi öncesi kâr ile amortisman toplanarak elde edilen değerin varlıklara bölünmesiyle hesaplanmıştır. Duran varlıkların değişimi ile amortisman toplanıp varlıklara bölünerek nakit akışı değişkeni bulunmuştur. Kurumsal yönetim değişkeni için BİST Kurumsal Yönetim Endeksi (BIST-XKURY) kapsamındaki şirketler için 1, diğerleri için 0 olarak tanımlanan gölge değişken kullanılmıştır. 
Tablo 1: Değişkenlerin Tanımlanması

\begin{tabular}{|c|c|c|c|}
\hline Değişken & Kisaltma & Tanım & $\begin{array}{l}\text { Beklenen } \\
\text { Etki }\end{array}$ \\
\hline Nakit tutma oranı & NTO & Nakit ve benzeri değerler / Varlıklar & \\
\hline Büyüme firsatları & PDO & $\begin{array}{l}\text { (Varlıklar- Özsermayenin defter } \\
\text { değeri + Özsermayenin piyasa } \\
\text { değeri) / Varlıklar }\end{array}$ & Pozitif \\
\hline Kaldıraç & KAL & $\begin{array}{l}\text { Kısa ve uzun vadeli yükümlülükler / } \\
\text { Varlıklar }\end{array}$ & Negatif \\
\hline Şirket büyüklüğü & BÜY & Varlıkların logaritması & Pozitif \\
\hline Net çalışma sermayesi & NÇS & $\begin{array}{l}\text { (Dönen varlıklar - Nakit ve nakit } \\
\text { benzeri değerler - Kısa vadeli } \\
\text { yükümlülükler) / Varlıklar }\end{array}$ & Negatif \\
\hline Nakit akış1 & NAK & $\begin{array}{l}\text { (Vergi öncesi kâr + Amortisman) / } \\
\text { Varlıklar }\end{array}$ & Pozitif \\
\hline Sermaye harcamaları & SHAR & $\begin{array}{l}\text { (Duran varlıkların değişimi + } \\
\text { Amortisman) / Varlıklar }\end{array}$ & Negatif \\
\hline Kurumsal yönetim & KYÖN & $\begin{array}{l}\text { BIST-XKURY kapsamındaki } \\
\text { şirketler için 1; diğerleri için } 0\end{array}$ & Negatif \\
\hline
\end{tabular}

Oluşturulan modellerde kullanılan değişkenlerin betimleyici istatistikleri aşağıdaki tabloda sunulmuştur. Örneklemde yer alan toplam 315 şirketin 2010 ve 2019 yılları arasındaki 2514 şirket-yıl gözlemi yapılan analizlere dâhil edilmiştir.

Ortalama nakit tutma oran $1 \% 9,97$ iken tanımın paydasında net varlıklar (varlıklar - nakit ve benzeri değerler) kullanıldığında ortalama nakit tutma oranı (net) $\% 15,03$ olarak tespit edilmiştir. Ortalama kaldıraç \%54,81 olup örneklemdeki şirketlerin varlıklarının ortalama olarak yarısının borçlardan oluştuğu anlaşılmaktadır. Ortalama net çalışma sermayesinin \%2,72 olması dikkate alındığında, örneklemdeki şirketlerin kısa vadeli yükümlülüklerini karşılayacak varlıklara sahip olduğu ve varlıkların \%2,72'si kadar fazla kaynak bulunduğu söylenebilir. Örneklemdeki şirketlerin, ortalama olarak varlıkların $\% 6,99$ oranında nakit akışına sahip olduğu ve \%4,87'si oranında sermaye harcaması yaptıkları yapılan gözlemler arasındadır.

Değişkenlerin tanımlamaları Tablo 1'de yapılmış olup tanımlamaların paydasında varlıklar ve net varlıklar (varlıklar - nakit ve benzeri değerler) kullanılarak hesaplanan değişkenlerin betimleyici istatistikleri sırasıyla Panel A ve Panel B'de sunulmuştur. 
Nakit Tutma Oranının Finansal ve Kurumsal Belirleyicileri: Borsa İstanbul Üzerine Bir Inceleme

Tablo 2: Betimleyici Istatistikler

\begin{tabular}{|c|c|c|c|c|c|}
\hline Değişken & $\begin{array}{l}\text { Gözlem } \\
\text { sayısı }\end{array}$ & Ortalama & $\% 25$ & Ortanca & $\% 75$ \\
\hline \multicolumn{6}{|c|}{ Panel A: Değişkenlerin paydasında varlıklar kullanıldı̆̆ında } \\
\hline NTO & 2514 & 0,0998 & 0,0150 & 0,0548 & 0,1406 \\
\hline PDO & 2514 & 1,5153 & 0,9525 & 1,1761 & 1,5925 \\
\hline KAL & 2514 & 0,5481 & 0,3206 & 0,5327 & 0,7062 \\
\hline BÜY & 2514 & 6,5122 & 5,1504 & 6,4110 & 7,7207 \\
\hline NÇS & 2514 & 0,0272 & $-0,0770$ & 0,0408 & 0,1792 \\
\hline NAK & 2514 & 0,0699 & 0,0073 & 0,0598 & 0,1246 \\
\hline SHAR & 2514 & 0,0487 & 0,0099 & 0,0286 & 0,0594 \\
\hline KYÖN & 2514 & 0,1030 & 0 & 0 & 0 \\
\hline \multicolumn{6}{|c|}{ Panel B: Değiskenlerin paydasında net varlıklar kullanıldığında } \\
\hline NTO & 2514 & 0,1503 & 0,0152 & 0,0580 & 0,1636 \\
\hline PDO & 2514 & 1,7919 & 1,0358 & 1,3140 & 1,8428 \\
\hline KAL & 2514 & 0,6066 & 0,3624 & 0,5831 & 0,7663 \\
\hline BÜY & 2514 & 6,5122 & 5,1504 & 6,4110 & 7,7207 \\
\hline NÇS & 2514 & 0,0320 & $-0,0865$ & 0,0452 & 0,2059 \\
\hline NAK & 2514 & 0,0911 & 0,0074 & 0,0671 & 0,1446 \\
\hline SHAR & 2514 & 0,0549 & 0,0110 & 0,0323 & 0,0667 \\
\hline KYÖN & 2514 & 0,1030 & 0 & 0 & 0 \\
\hline
\end{tabular}

Ortalama nakit tutma oranlarının yıllar içindeki değişimi aşağıdaki şekilde sunulmuş olup örneklemdeki şirketlerin nakit tutma oranlarının çok geniş olmayan bir aralıkta dalgalandığ 1 gözlemlenmiştir. 2019 yılında nakit tutma oranı son on yılın en yüksek seviyesine ulaşmıştır.

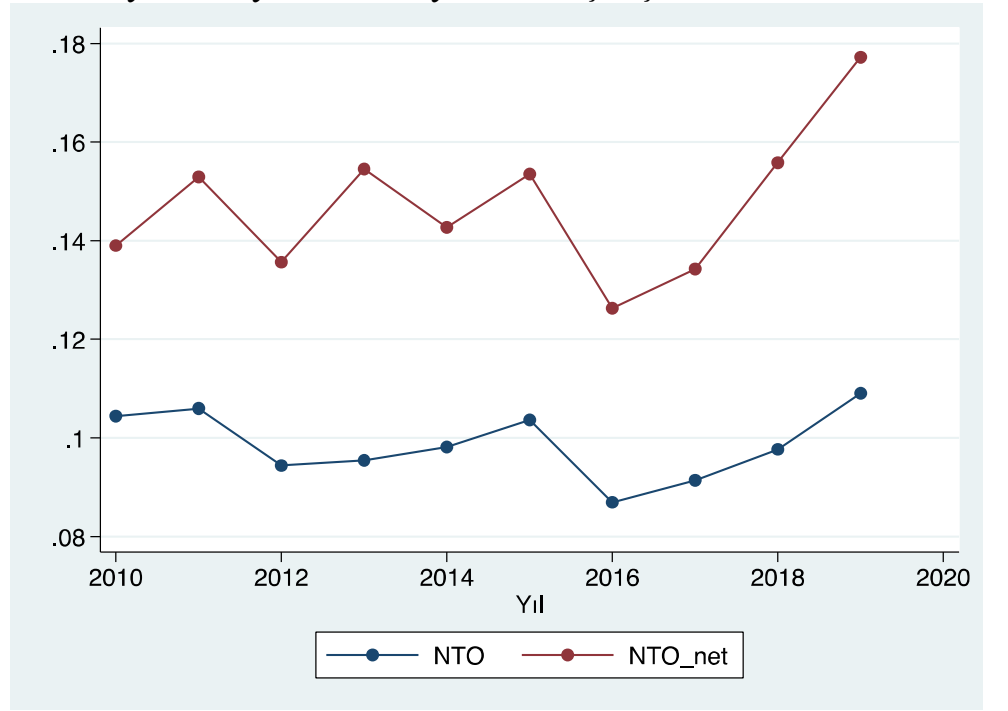

Şekil 1: Ortalama Nakit Tutma Oranları Değişimi 
NTO değişkeninin tanımlaması Tablo 1'de yapılmış olup tanımlamanın paydasında varlıklar ve net varlıklar (varlıklar - nakit ve benzeri değerler) kullanılarak NTO_net hesaplanmıştır.

\section{Bulgular}

Nakit tutma oranının belirleyicilerini araştırmak için oluşturulan modellerde kullanılan değişkenler arasındaki korelasyon katsayıları aşağıdaki tabloda sunulmuştur. Panel A'da büyüme firsatları (PDO) ile nakit akışı (NAK) ve şirket büyüklügü (BÜY) ile kurumsal yönetim (KYÖN) arasında; Panel B'de ise büyüme firsatları (PDO) ile nakit akışı (NAK) arasında nispeten yüksek korelasyon tespit edilmiş ise de kabul edilebilir sınırlar içinde kalmaktadır. Genel olarak bağımsız değişkenler arasında yüksek korelasyon bulunmamıştır. Kurumsal yönetim ile şirket büyüklügü arasındaki yüksek korelasyon, kurumsal yönetim endeksindeki şirketlerin daha çok büyük şirketler olduğunu işaret etmektedir. 31.08.2007 tarihinden itibaren hesaplanmaya başlanılan endeks, kurumsal yönetim ilkelerine uyum notu ortalama olarak 10 üzerinden en az 7 olan şirketleri kapsamaktadır. Kurumsal yönetim ilkelerine uyumu belirli düzeyde olan şirketlerin fiyat ve getiri performanslarını ölçmeyi amaçlayan endeks kapsamında halen 49 şirket bulunmaktadır. Daha çok büyük şirketlerin dahil olduğu endeksin doğası korelasyon analizi bulgusu ile de ortaya çıkan sonuçlardan kısmen anlaşılmaktadır.

Tanımlamaların paydasında varlıklar kullanılmasıyla elde edilen değişkenlerin korelasyon katsayıları Panel A'da, tanımlamaların paydasında net varlıklar (varlıklar - nakit ve benzeri değerler) kullanılmasıyla elde edilen değişkenlerin korelasyon katsayıları ise Panel B'de sunulmaktadır. ***, ** ve * sırasıyla $\% 1, \% 5$ ve $\% 10$ düzeylerindeki anlamlıl1kları göstermektedir.

Tablo 3: Korelasyon Matrisi

\begin{tabular}{llllllll}
\hline Değişken & NTO & PDO & KAL & BÜY & NÇS & NAK & SHAR \\
\hline
\end{tabular}

Panel A: Değişkenlerin paydasında varlıklar kullanıldı ̆̆ında

\begin{tabular}{lccccccc} 
PDO & $0,12^{* * *}$ & & & & & \\
KAL & $-0,22^{* * *}$ & $0,18^{* * *}$ & & & & & \\
BÜY & $0,14^{* * *}$ & $-0,17^{* * *}$ & $0,05^{* *}$ & & & & \\
NÇS & 0,03 & $-0,17 * * *$ & $-0,28^{* * *}$ & $-0,12^{* * *}$ & & & \\
NAK & $0,16^{* * *}$ & $0,34 * * *$ & $-0,10^{* * *}$ & 0,02 & $0,09 * * *$ & & \\
SHAR & $-0,04^{* *}$ & 0,03 & 0,01 & $0,10^{* * *}$ & $-0,01$ & $0,06 * * *$ & \\
KYÖN & $0,11^{* * *}$ & $-0,02$ & 0,01 & $0,38^{* * *}$ & $-0,0189$ & 0,02 & $-0,03$ \\
\hline
\end{tabular}


Nakit Tutma Oraninin Finansal ve Kurumsal Belirleyicileri: Borsa İstanbul Üzerine Bir Inceleme

\begin{tabular}{|c|c|c|c|c|c|c|c|}
\hline \multirow{2}{*}{$\begin{array}{l}\text { Değișken } \\
\text { Panel B: }\end{array}$} & NTO & PDO & KAL & BÜY & NÇS & NAK & SHAR \\
\hline & $\overline{\text { Değişskenler }}$ & in paydast & da net varl & Iar kullan & ldı̆̆ı̆ıda & & \\
\hline PDO & $0,53 * * *$ & & & & & & \\
\hline KAL & $-0,00$ & $0,12 * * *$ & & & & & \\
\hline BÜY & $0,03 *$ & $-0,14 * * *$ & $0,09 * * *$ & & & & \\
\hline NÇS & $-0,00$ & $-0,11 * * *$ & $-0,28 * * *$ & $-0,14 * * *$ & & & \\
\hline NAK & $0,30^{* * *}$ & $0,41 * * *$ & $-0,09 * * *$ & 0,02 & $0,10^{* * *}$ & & \\
\hline SHAR & $0,04 *$ & $0,07 * * *$ & $-0,01$ & $0,11 * * *$ & $-0,01$ & $0,10^{* * *}$ & \\
\hline KYÖN & 0,03 & $-0,02$ & $0,04 * *$ & $0,38 * * *$ & $-0,03$ & 0,02 & $-0,03$ \\
\hline
\end{tabular}

\subsection{Panel Verinin Dură̆anlı̆̆}

Dengesiz panellerin durağanlığını test etmek için uygun olan Fisher tipi panel birim kök testlerinden Phillips-Perron testi kullanılmıștır. Testin sıfır hipotezi, tüm panellerin birim kök içerdiğine ilişkindir. Alternatif hipotez ise paneldeki en az bir serinin durağan olduğunu ileri sürmektedir. Farklı alternatifler ile bir karşılaştırma yapan Maddala ve Wu (1999), teknik detaylara daha çok, cevap aranan sorulara ise daha az yoğunlaşan diğer tekniklerdense Fisher tipi testlerin basit, anlaşılır ve alternatiflerinden daha iyi olduğu sonucuna varmıştır. Aşağıdaki tabloda sunulan test sonuçlarına göre tüm değişkenler için sıfır hipotezi reddedilerek paneldeki en az bir serinin durağan olduğu anlaşılmıştır.

Tanımlamaların paydasında varlıklar kullanılmasıyla elde edilen değişkenlere ilişkin istatistikleri Panel A'da, tanımlamaların paydasında net varlıklar (varlıklar - nakit ve benzeri değerler) kullanılmasıyla elde edilen değişkenlere ilişkin istatistikler ise Panel $\mathrm{B}$ 'de sunulmaktadır. ***, ** ve * sirasıyla $\% 1, \% 5$ ve $\% 10$ düzeylerindeki anlamlılıkları göstermektedir.

Tablo 4: Birim Kök Testi Sonuçları

\begin{tabular}{ccc}
\hline Değişken & Panel $\boldsymbol{A}$ & Panel $\boldsymbol{B}$ \\
\hline NTO & $1895,24 * * *$ & $2118,44 * * *$ \\
PDO & $2044,35 * * *$ & $1853,58 * * *$ \\
KAL & $1084,76 * * *$ & $1244,33 * * *$ \\
BÜY & $776,85 * * *$ & $776,85 * * *$ \\
NÇS & $1343,97 * * *$ & $1457,17 * * *$ \\
NAK & $1881,86 * * *$ & $1948,09 * * *$ \\
SHAR & $2184,43 * * *$ & $2144,64 * * *$ \\
\hline
\end{tabular}

\subsection{Statik Panel Veri Analizi}

Uygun tahmincinin belirlenebilmesi için havuzlanmış en küçük kareler (HEKK), sabit etkiler ve tesadüfi etkiler tahmincileri kullanılarak modeller analiz edilmiştir. Tahmincilerin tutarlılığını ve etkinliğini belirlemek amacıyla Chow testinden türetilen $\mathrm{F}$ testi, Breusch-Pagan LM testi ve Hausman testi 
kullanılmıştır. Chow testinden uyarlanan $F$ testi, sabit etkiler ile HEKK tahmincileri arasında karar verilmesine yardımcı olmaktadır. Testin sıfır hipotezine göre birim etkiler sıfıra eşittir. Sabit etkiler tahmincisinin kullanılabilmesi için sıfır hipotezinin reddedilmesi gerekmektedir. Tesadüfi etkiler ile HEKK tahmincileri arasında karar verilmesine yardımcı olan Breusch ve Pagan LM testinin estin sifir hipotezi ise birimler arasında önemli bir fark olmadığıdır. Tesadüfi etkiler tahmincisinin kullanılabilmesi için sıfır hipotezinin reddedilmesi gerekmektedir. Son olarak sabit etkiler ile tesadüfi etkiler tahmincileri arasında karar verilebilmesi için kullanılan Hausman testinin sıfir hipotezi, birime özgü etkilerin tesadüfi olduğudur. Sıfır hipotezinin reddedilmesi durumunda sabit etkiler tahmincisi daha tutarlı olacaktır.

Aşağıdaki tabloda verilen sonuçlara göre F testi ve Breusch-Pagan LM testi sonuçları ile bu testlerin sıfir hipotezleri reddedilerek sabit etkiler ve tesadüfi etkiler tahmincilerinin HEKK tahmincisine göre daha tutarlı ve etkin olduğu anlaşılmaktadır. Hausman testi sonuçlarına göre ise birim etkilerin tesadüfi olduğuna dair sıfır hipotezi reddedildiğinden sabit etkiler tahmincisi ile elde edilen bulguların daha tutarlı olduğu anlaşılmıştır.

Parametre tahminleri ve parantez içinde standart hatalar sunulmaktadır. HEKK ve sabit etkiler tahmincileri için model testi, $F$ testi sonucu iken tesadüfi etkiler tahmincisi için Wald testi sonucudur. Etki testi ise sabit etkiler tahmincisi için F testi sonucu ve tesadüfi etkiler tahmincisi için Breusch-Pagan LM testi sonucudur. Tanımlamaların paydasında varlıklar kullanılmasıyla elde edilen değişkenler ile oluşturulan model Panel A'da, tanımlamaların paydasında net varlıklar (varlıklar - nakit ve benzeri değerler) kullanılmasıyla elde edilen değiş̧kenler ile oluşturulan model ise Panel $\mathrm{B}$ 'de sunulmaktadır. ***, ** ve * sırasıyla \%1, \%5 ve \%10 düzeylerindeki anlamlılıkları göstermektedir.

Tablo 5: Uygun Tahmincinin Belirlenmesi ve Statik Panel Veri Tahminleri

\begin{tabular}{|c|c|c|c|c|c|c|}
\hline & \multicolumn{3}{|c|}{ Panel $A$} & \multicolumn{3}{|c|}{ Panel B } \\
\hline & HEKK & $\begin{array}{c}\text { Sabit } \\
\text { Etkiler }\end{array}$ & $\begin{array}{c}\text { Tesadüfi } \\
\text { Etkiler }\end{array}$ & HEKK & $\begin{array}{c}\text { Sabit } \\
\text { Etkiler }\end{array}$ & $\begin{array}{c}\text { Tesadüfi } \\
\text { Etkiler }\end{array}$ \\
\hline PDO & $\begin{array}{c}0,015^{* *} \\
(0,007)\end{array}$ & $\begin{array}{c}0,004 * * \\
(0,002)\end{array}$ & $\begin{array}{c}0,005^{* * *} \\
(0,002)\end{array}$ & $\begin{array}{c}0,100 * * * \\
(0,035)\end{array}$ & $\begin{array}{c}0,066 * * * \\
(0,004)\end{array}$ & $\begin{array}{c}0,074 * * * \\
(0,004)\end{array}$ \\
\hline KAL & $\begin{array}{c}-0,157^{* * * *} \\
(0,030)\end{array}$ & $\begin{array}{c}-0,131 * * * \\
(0,011)\end{array}$ & $\begin{array}{c}-0,137^{* * * *} \\
(0,010)\end{array}$ & $\begin{array}{c}-0,042 \\
(0,066)\end{array}$ & $\begin{array}{c}0,205 * * * \\
(0,029)\end{array}$ & $\begin{array}{c}0,124 * * * \\
(0,026)\end{array}$ \\
\hline BÜY & $\begin{array}{c}0,009 * * * \\
(0,004)\end{array}$ & $\begin{array}{c}0,016 * * * \\
(0,005)\end{array}$ & $\begin{array}{c}0,011^{* * *} \\
(0,003)\end{array}$ & $\begin{array}{c}0,022 * * \\
(0,009) \\
\end{array}$ & $\begin{array}{c}0,057^{* * * *} \\
(0,013)\end{array}$ & $\begin{array}{c}0,027 * * * \\
(0,006) \\
\end{array}$ \\
\hline NÇS & $\begin{array}{c}-0,127 * * * \\
(0,027)\end{array}$ & $\begin{array}{c}-0,125 * * * \\
(0,011)\end{array}$ & $\begin{array}{c}-0,126^{* * *} \\
(0,010)\end{array}$ & $\begin{array}{c}0,021 \\
(0,055)\end{array}$ & $\begin{array}{c}0,065^{* * *} \\
(0,029)\end{array}$ & $\begin{array}{l}0,047^{*} \\
(0,027)\end{array}$ \\
\hline NAK & $\begin{array}{c}0,041 \\
(0,043)\end{array}$ & $\begin{array}{c}0,018 * * * \\
(0,006)\end{array}$ & $\begin{array}{c}0,018^{* * *} \\
(0,006)\end{array}$ & $\begin{array}{c}0,095 \\
(0,166)\end{array}$ & $\begin{array}{c}0,053 * * * \\
(0,017)\end{array}$ & $\begin{array}{c}0,047 * * * \\
(0,017)\end{array}$ \\
\hline SHAR & $\begin{array}{c}-0,099 * * \\
(0,041)\end{array}$ & $\begin{array}{c}-0,094 * * * \\
(0,029)\end{array}$ & $\begin{array}{c}-0,094 * * * \\
(0,028)\end{array}$ & $\begin{array}{c}-0,077 \\
(0,104)\end{array}$ & $\begin{array}{l}-0,085 \\
(0,076)\end{array}$ & $\begin{array}{c}-0,079 \\
(0,071)\end{array}$ \\
\hline KYÖN & $\begin{array}{c}0,021 \\
(0,017) \\
\end{array}$ & $\begin{array}{l}-0,004 \\
(0,017)\end{array}$ & $\begin{array}{c}0,007 \\
(0,013) \\
\end{array}$ & $\begin{array}{l}-0,013 \\
(0,033)\end{array}$ & $\begin{array}{c}-0,019 \\
(0,048)\end{array}$ & $\begin{array}{l}-0,022 \\
(0,035)\end{array}$ \\
\hline
\end{tabular}


Nakit Tutma Oranının Finansal ve Kurumsal Belirleyicileri: Borsa İstanbul Üzerine Bir Inceleme

\begin{tabular}{lcccccc}
\hline sabit terim & $0,107^{* * *}$ & $\mathbf{0 , 0 6 8} * *$ & $0,101^{* * *}$ & $-0,151^{*}$ & $\mathbf{- 0 , 4 6 2 * * *}$ & $-0,236^{* * *}$ \\
& $(0,031)$ & $\mathbf{( 0 , 0 3 0 )}$ & $(0,018)$ & $(0,084)$ & $\mathbf{( 0 , 0 8 5 )}$ & $(0,045)$ \\
Model testi & $8,99^{* * *}$ & $\mathbf{2 2 , 9 5 * * *}$ & $239,24 * * *$ & $5,61 * * *$ & $\mathbf{6 7 , 1 8 * * *}$ & $578,79 * * *$ \\
$\mathrm{R}^{2}$ & 0,163 & $\mathbf{0 , 1 3 7}$ & 0,162 & 0,306 & $\mathbf{0 , 1 6 2}$ & 0,297 \\
$\mathrm{~N}$ & 2514 & $\mathbf{2 5 1 4}$ & 2514 & 2514 & $\mathbf{2 5 1 4}$ & 2514 \\
Etki testi & & $\mathbf{1 7 , 2 4 * * *}$ & $4196^{* * *}$ & & $\mathbf{1 1 , 5 7 * * *}$ & $2341 * * *$ \\
Hausman & & & $18,18^{* *}$ & & & $106,59 * * *$ \\
testi & & & & & & \\
\hline
\end{tabular}

Yapılan testler sonucunda, alternatiflerine göre daha tutarlı ve etkin sonuçlar verdiği anlaşılan sabit etkiler tahmincisi kullanılarak elde edilen statik panel veri analizi bulgularına göre büyüme firsatları, şirket büyüklüğü ve nakit akışı değişkenleri, nakit tutma oranını pozitif ve istatistiksel olarak anlamlı olarak etkilerken kaldıraç, net çalışma sermayesi ve sermaye harcamaları değişkenleri negatif ve istatistiksel olarak anlamlı olarak etkilemektedir. Tanımlamaların paydasında net varlıklar (varlıklar - nakit ve benzeri değerler) kullanılmasıyla elde edilen değişkenler ile oluşturulan modelde ise kaldıraç ve net çalışma sermayesi değişkenleri katsayılarının işareti değişmiş ve ilk modelde istatistiksel olarak anlamlı olan sermaye harcamaları değişkeninin katsayısı anlamsız hale gelmiştir.

Nakit tutma oranının, büyüme firsatları değişkeni ile arasındaki pozitif ilişki ve sermaye harcamaları ile arasındaki negatif ilişki, dengeleme ve finansman hiyerarşisi teorilerinin beklentileriyle uyumluyken şirket büyüklügü ve nakit akışı değişkenleri ile arasındaki pozitif ilişki finansman hiyerarşisi ve nakit akış teorilerinin beklentileriyle uyumludur. Kaldıraç ile nakit tutma oranı arasında tespit edilen negatif ilişki ise dengeleme, finansman hiyerarşisi ve nakit akış teorilerinin her üçünün de beklentileri ile örtüşmektedir. Kurumsal yönetim değişkeni katsayısının işareti, serbest nakit akış teorisinin beklentileri doğrultusunda, pozitif iken istatistiksel olarak anlamlı bulunmamıştır.

\subsection{Dinamik Panel Veri Analizi}

Dengeleme teorisine göre şirketlerin bir hedef nakit tutma oranı bulunmakta ve hedefe doğru bir ayarlama yapılmaktadır. Ancak finansman hiyerarşisi teorisi bir hedef oran bulunmamaktadır. Şirketlerin hedef nakit tutma oranı bulunduğu ve hedefe doğru bir ayarlama yaptığını öne süren dengeleme teorisinin öngörüsünü sınamak amacıyla bağımlı değişkenin gecikmeli değerinin açıklayıcı değişken olarak eklendiği dinamik panel veri modeli kullanılmıştır. Nickell (1981), dinamik panel veri modellerinin en küçük kareler ile tahmin edilmesi durumunda $y_{i, t-1}$ ile hata terimindeki sabit etkiler ilişkili olacağından dinamik panel yanlılığının oluşacağını ortaya koymaktadır. Bir açılayıcı değişken ile hata teriminin ilişkili olması, EKK tahmincisinin tutarlı olabilesi için gerekli bir varsayımın ihlalidir. Ortaya çıkan içsellik probleminden kaçınmanın yolu, ya sabit etkileri ortadan kaldıracak şekilde 
verilerin dönüştürülmesi veya $y_{i, t-1}$ ile benzer içsel değişkenler için araç değişkenler kullanılmasıdır. Dinamik panel veri analizinde GMM tekniklerinin kullanılması durumunda, her bir zaman aralığı ve mümkün olan gecikmeler için birer araç değişken oluşturulması "çok fazla araç değişken problemi" görülmesine neden olabilecektir. Araç değişken sayısını düşürmenin yollarından biri, gecikme uzunluğunun kısaltılması iken ikincisi araç değişken setinin daraltılmasıdır (Roodman, 2009: 149). Windmeijer (2005) yaptığı karşılaştırma ile gecikme uzunluğunu sınırlayarak daha az araç değişken kullanılmasıyla GMM tahmininin daha etkin hale geleceğini göstermiştir.

Her bir zaman aralığı ve mümkün olan tüm gecikmeler için birer araç değiş̧ken oluşturan fark GMM ve sistem GMM teknikleri kullanılabilecekse de Arellano ve Bover (1995) tarafından geliştirilen sistem GMM, Arellano ve Bond (1991) tarafindan tanımlanan fark GMM tekniğinden daha etkin bir tahmin metodudur. Arellano-Bond tahmincisinde kullanılan birinci fark dönüşümünün zayıf yanı, dengesiz panellerde açıklıkları şişirmeleridir. Hatta birinci farkları olmayan veri setleri oluşturulması dahi mümkündür. Arellano ve Bover (1995) tarafından ileriye doğru dikeysel sapma adı verilen ikinci genel dönüşüm yapılarak değişkenin mevcut gözleminden bir önceki gözleminin çıkarılması yerine, değişkenin gelecekteki tüm gözlemlerinin ortalamasının mevcut gözleminden çıkarılması önerilmiştir. Böylece veri eksikliğinin etkisinin azaltılması amaçlanmıştır.

Seri korelasyon birkaç periyot sonra düşük olacağından ve daha uzun gecikmelerin herhangi bir yeni bilgi eklemeyeceğinden sistem GMM tahminlerinde araç değişken çoğalmasından kaçınmak için en çok 5 gecikme kullanılacak şekilde kısıtlama yapılmıştır.

GMM tahmininin geçerli olması için sağlanması gereken varsayımlar, otokorelasyon ve Hansen testleriyle sınanmıştır. Arellano ve Bond (1991) tarafindan önerilen otokorelasyon testinin sifir hipotezi, modellerde otokorelasyon olmadığı iken Hansen $J$ testinin sıfır hipotezi, tüm araç değişkenlerin ortak geçerli olduğudur. Testlerin sıfır hipotezleri reddedilememekte, kurulan modellerde ikinci dereceden otokorelasyon olmadığı ve tüm araç değişkenlerin ortak geçerli olduğu anlaşılmaktadır.

Dengeleme teorisinin öngörüsü doğrultusunda oluşturulan kısmi ayarlama modeline göre her şirket hedef oranına yaklaşmaktadır. Hedef kaldıracın şirketler arasında ve zaman içinde değişiklik göstermesine imkân sağlayan kısmi ayarlama modeline göre her şirketin ayarlama hızı $(\lambda)$ aynıdır. $N T O_{i, t}, i$ şirketinin $t$ zamanındaki nakit tutma oranı, $X_{i, t}$, nakit tutma oranının belirleyicisi olan şirket özelliklerinin bir vektörü; $\alpha_{i}$ ise birime özgü olan sabit etkiler olmak üzere kısmi ayarlama modeli aşağıdaki gibi ifade edilir.

$$
N T O_{i, t+1}=(\lambda \beta) X_{i, t}+c \alpha_{i}+(1-\lambda) N T O_{i, t}+\varepsilon_{i, t+1}
$$

Sistem GMM tahmincisi ve gecikme kısıtlama tekniği kullanılarak yapılan analizin bulgularına göre gecikmeli bağımlı değişkenin katsayısı 
Nakit Tutma Oranının Finansal ve Kurumsal Belirleyicileri: Borsa İstanbul Üzerine Bir Inceleme

istatistiksel olarak anlamlı olup dengeleme teorisinin beklentisi doğrultusunda, şirketlerin birer hedef nakit tutma oranı bulunmakta ve bu hedefe doğru ayarlamalar yapılmaktadır. Tanımlamaların paydasında varlıklar kullanılmasıyla elde edilen değişkenler ile oluşturulan modelin sistem GMM tahminine göre hedef ayarlama hızı \%35,49 iken tanımlamaların paydasında net varlıklar kullanılmasıyla elde edilen değişkenler ile oluşturulan modelin sistem GMM tahminine göre hedef ayarlama hızı \%49,95 olarak bulunmuştur.

Panel A'da katsayı tahminleri sunulan modelin, statik ve dinamik panel veri analizinde katsayılarının işaretleri ve istatistiksel olarak anlamlılıkları değişmemiştir. Ancak Panel B'de katsayı tahminleri sunulan model için yapılan statik panel veri analizinde kaldıraç, net çalışma sermayesi ve nakit akışı değişkenleri katsayıları istatistiksel olarak anlamlıyken dinamik panel veri analizinde katsayıların işaretleri aynı kalmakla birlikte istatistiksel olarak anlamlılıkları kalmamıştır. Bununla birlikte statik panel veri analizinde istatistiksel olarak anlamlı olmayan sermaye harcamaları değişkeni katsayısı, dinamik panel veri analizinde negatif ve istatistiksel olarak anlamlıdır.

İki aşamalı fark GMM ve sistem GMM tahminleri ve parantez içinde Windmeijer düzeltmesi yapılmış standart hatalar sunulmaktadır. Açıklayıcı değişkenler, önceden belirlenmiş olarak alınmış ve sistem GMM tahminlerinde araç değişken çoğalmasından kaçınmak için en çok 5 gecikme kullanılacak şekilde kısıtlama yapılmıştır. Sabit terimler ve zaman gölge değişkenleri raporlanmamıştır. Hedef ayarlama hızı, hedef kaldıraç oranına doğru hızı ifade etmekte olup $\lambda$ ile gösterilmektedir. Tanımlamaların paydasında varlıklar kullanılmasıyla elde edilen değişkenler ile oluşturulan model Panel A'da, tanımlamaların paydasında net varlıklar (varlıklar - nakit ve benzeri değerler) kullanılmasıyla elde edilen değişkenler ile oluşturulan model ise Panel B'de sunulmaktadır. $* * *, * *$ ve $*$ sirasiyla $\% 1, \% 5$ ve $\% 10$ düzeylerindeki anlamlılıkları göstermektedir.

Tablo 6: Dinamik Panel Veri Tahminleri

\begin{tabular}{lcccc}
\hline & \multicolumn{2}{c}{ Panel $\boldsymbol{A}$} & \multicolumn{2}{c}{ Panel B } \\
\hline \multirow{2}{*}{ Fark GMM } & Sistem GMM & Fark GMM & $\begin{array}{c}\text { Sistem } \\
\text { GMM }\end{array}$ \\
\hline \multirow{2}{*}{ PDO } & $0,2080^{* * *}$ & $\mathbf{0 , 6 4 5 1} * * *$ & $0,1756^{* *}$ & $\mathbf{0 , 5 0 0 5 * * *}$ \\
& $(0,0494)$ & $\mathbf{( 0 , 0 4 5 4 )}$ & $(0,0791)$ & $(\mathbf{0 , 0 7 3 5 )}$ \\
\hline \multirow{2}{*}{ KAL } & 0,0035 & $\mathbf{0 , 0 0 7 0 *}$ & $0,0493^{* * *}$ & $\mathbf{0 , 0 5 0 7 * * *}$ \\
& $(0,0034)$ & $\mathbf{( 0 , 0 0 4 0 )}$ & $(0,0141)$ & $(\mathbf{0 , 0 1 5 5 )}$ \\
\hline \multirow{2}{*}{ BÜY } & $-0,0796^{* * *}$ & $\mathbf{- 0 , 0 7 8 9 * * *}$ & 0,1855 & $\mathbf{0 , 0 1 1 6}$ \\
& $(0,0257)$ & $\mathbf{( 0 , 0 1 8 0 )}$ & $(0,12582)$ & $\mathbf{( 0 , 0 8 9 0 )}$ \\
\hline \multirow{2}{*}{ NÇS } & 0,0175 & $\mathbf{0 , 0 0 8 1 * * *}$ & $0,0714^{*}$ & $\mathbf{0 , 0 2 3 8 * * *}$ \\
& $(0,0150)$ & $\mathbf{( 0 , 0 0 2 4 )}$ & $(0,0402)$ & $\mathbf{( 0 , 0 0 8 3 )}$ \\
\hline
\end{tabular}


Tablo 6 Devamı: Dinamik Panel Veri Tahminleri

\begin{tabular}{lcccc}
\hline & \multicolumn{2}{c}{ Panel $\boldsymbol{A}$} & \multicolumn{2}{c}{ Panel $\boldsymbol{B}$} \\
\hline & Fark GMM & Sistem GMM & Fark GMM & $\begin{array}{c}\text { Sistem } \\
\text { GMM }\end{array}$ \\
\hline NAK & $\mathbf{0 , 0 1 6 4 * *}$ & $0,0359^{* *}$ & $\mathbf{0 , 0 4 1 6}$ & 0,1447 \\
& $\mathbf{( 0 , 0 0 7 5 )}$ & $(0,0153)$ & $\mathbf{( 0 , 0 5 6 0 )}$ & $(0,0900)$ \\
\hline SHAR & $-0,0327$ & $\mathbf{- 0 , 0 7 9 9 * *}$ & 0,0306 & $\mathbf{- 0 , 2 2 2 7 *}$ \\
& $(0,0470)$ & $\mathbf{( 0 , 0 3 9 3 )}$ & $(0,1452)$ & $\mathbf{( 0 , 1 1 9 1 )}$ \\
\hline KYÖN & $-0,0383$ & $\mathbf{- 0 , 0 0 4 1}$ & $-0,1420$ & $\mathbf{- 0 , 0 4 0 0}$ \\
& $(0,0820)$ & $\mathbf{( 0 , 0 0 8 9 )}$ & $(0,2218)$ & $\mathbf{( 0 , 0 2 5 0 )}$ \\
\hline Gözlem sayıs1 & 1841 & $\mathbf{2 1 5 4}$ & 1841 & $\mathbf{2 1 5 4}$ \\
Grup sayıs1 & 303 & $\mathbf{3 1 3}$ & 303 & $\mathbf{3 1 3}$ \\
Araç değişken sayıs1 & 300 & $\mathbf{3 0 6}$ & 300 & $\mathbf{3 0 6}$ \\
F testi & $4,48^{* * *}$ & $\mathbf{3 2 , 0 1 * * *}$ & $3,84 * * *$ & $\mathbf{4 1 , 2 7 * * *}$ \\
AR (2) & $-0,56$ & $\mathbf{0 , 9 1}$ & $-0,37$ & $\mathbf{0 , 5 1}$ \\
p değeri & 0,57 & $\mathbf{0 , 3 6}$ & 0,71 & $\mathbf{0 , 6 1}$ \\
Hansen J & 292,63 & $\mathbf{2 9 3 , 4 1}$ & 291,31 & $\mathbf{3 0 1 , 2 8}$ \\
p değeri & 0,32 & $\mathbf{0 , 3 9}$ & 0,34 & $\mathbf{0 , 2 7}$ \\
\hline Hedef ayarlama hızı $(\lambda)$ & $\mathbf{0 , 7 9 2 0}$ & 0,3549 & $\mathbf{0 , 8 2 4 4}$ & 0,4995 \\
\hline
\end{tabular}

Sonuç

Şirketlerin olağan faaliyetlerini sürdürebilmesi için bir miktar nakit tutması gerektiği kuşkusuzdur. Ancak görünen odur ki birçok şirket olağan ihtiyaçlarını karşılayabilecek düzeyin üzerinde nakit tutmaktadır. Diğer taraftan şirketlerin nakit tutma eğilimleri zaman içinde değişmektedir. Bu değişim bazı ekonomilerde daha güçlü gözlemlenirken bazı ekonomilerde daha zayıf gerçekleşmektedir. Şirketlerin nakit tutma eğilimleri ve bunun zaman içinde değişmesi araştırmacıların ilgisini çekmiş, nakit tutma oranının belirleyicileri ve sonuçları üzerine zengin bir literatür meydana gelmiştir. Nakit tutma eğilimine ilişkin olarak gelişmiş ve gelişmekte olan ülkelerden alınan örneklemlerle yapılan birçok çalışmanın yanında ülkeler arasındaki farklılıkları inceleyen çalışmalar da literatürde yer almaktadır.

$\mathrm{Bu}$ çalışmada ele alınan Borsa İstanbul şirketleri üzerine de bazı çalışmalar bulunmaktadır. Ancak bu çalışmalarda ya kullanılacak tahmincinin etkin sonuçlar veremeyeceği kısa zaman aralıkları kullanılmış, ya yerel ve küresel kriz dönemlerini kapsayan ve kriz etkisinin ayrıştırılmadığı veri setleri üzerinde çalışılmış, ya da şirkete özel faktörlere ilişkin daha dar değişken setleri kullanılmıştır. Bu çalışmada, diğer alternatiflerine göre üstünlüğü literatürde kabul görmüş sistem GMM tekniği kullanılmış ve sistem GMM tekniği tarafindan üretilen araç değişkenler için oldukça yeterli bir zaman aralığı analiz edilmiştir. İkinci olarak yerel veya küresel krizlerin bulunmadığı 2010'lu yıllar üzerinde çalışılarak kriz etkisinin sirayet etmediği, güvenilir sonuçlara 
ulaşılmıştır. Son olarak, Borsa İstanbul'da işlem gören şirketlerin finansal tablolarına dayalı olarak, literatürde sıklıkla tercih edilen faktörlerden oluşan bir veri seti yanında kurumsal yönetimin etkisini araştırmak amacıyla gölge değişken kullanılmıştır.

Çalışmanın örneklemine dâhil olan 315 finans dışı şirketin 2010 ve 2019 y1lları arasında ortalama nakit tutma oranı \%9,97 iken tanımın paydasında net varlıklar (varlıklar - nakit ve benzeri değerler) kullanıldığında ortalama nakit tutma oranı (net) \%15,03 olarak tespit edilmiştir. Şirketlerin nakit tutma oranlarının çok geniş olmayan bir aralıkta dalgalandığı gözlemlenmiştir. 2019 yılında nakit tutma oranı son on yılın en yüksek seviyesine ulaşmıştır.

Sabit etkiler tahmincisi kullanılarak elde edilen statik panel veri analizi bulgularına göre büyüme firsatları, şirket büyüklüğü ve nakit akışı değişkenleri, nakit tutma oranını pozitif ve istatistiksel olarak anlamlı olarak etkilerken kaldıraç, net çalışma sermayesi ve sermaye harcamaları değişkenleri negatif ve istatistiksel olarak anlamlı olarak etkilemektedir. Tanımlamaların paydasında net varlıklar (varlıklar - nakit ve benzeri değerler) kullanılmasıyla elde edilen değişkenler ile oluşturulan modelde ise kaldıraç ve net çalışma sermayesi değişkenleri katsayılarının işareti değişmiş ve ilk modelde istatistiksel olarak anlamlı olan sermaye harcamaları değişkeninin katsayısı anlamsız hale gelmiştir. Dinamik panel veri analizi sonucunda, nakit tutma oranının bağımlı değişken olarak kullanıldığı modeldeki bağımsız değişken katsayılarının işaretleri ve istatistiksel olarak anlamlılıkları değişmemiştir. Ancak bağımlı değişken olarak nakit tutma oranı (net) kullanılan modeldeki kaldıraç, net çalışma sermayesi ve nakit akışı değişkenlerinin istatistiksel olarak anlamlıl1kları ortadan kalkarken sermaye harcamalarının negatif etkisi anlamlı hale gelmiştir.

Nakit tutma oranının, büyüme firsatları değişkeni ile arasındaki pozitif ilişki ve sermaye harcamaları ile arasındaki negatif ilişki, dengeleme ve finansman hiyerarşisi teorilerinin beklentileriyle uyumluyken şirket büyüklügü ve nakit akışı değişkenleri ile arasındaki pozitif ilişki finansman hiyerarşisi ve nakit akış teorilerinin beklentileriyle uyumludur. Kaldıraç ile nakit tutma oranı arasında tespit edilen negatif ilişki ise dengeleme, finansman hiyerarşisi ve nakit akış teorilerinin her üçünün de beklentileri ile örtüşmektedir. Kurumsal yönetim değişkeni katsayısının işareti, serbest nakit akış teorisinin beklentileri doğrultusunda, pozitif iken istatistiksel olarak anlamlı bulunmamıştır.

Sistem GMM tahmincisi ve gecikme kısıtlama tekniği kullanılarak yapılan analizin bulgularına göre gecikmeli bağımlı değişkenin katsayısı istatistiksel olarak anlamlı olup dengeleme teorisinin beklentisi doğrultusunda, şirketlerin birer hedef nakit tutma oranı bulunmakta ve bu hedefe doğru ayarlamalar yapılmaktadır. Tanımlamaların paydasında varlıklar kullanılmasıyla elde edilen değişkenler ile oluşturulan modelin sistem GMM tahminine göre hedef ayarlama hızı \%35,49 iken tanımlamaların paydasında net varlıklar (varlıklar - nakit ve benzeri değerler) kullanılmasıyla elde edilen 
değişkenler ile oluşturulan modelin sistem GMM tahminine göre hedef ayarlama hızı \% 49,95 olarak bulunmuştur.

İleride yapılacak çalışmalarda farklı finansal ve kurumsal faktörlerin kullanılması, modelin açıklama gücünü artıracak ve kurumsal faktörlerin etkisini ortaya çıkarabilecektir. İncelenen dönemler içindeki yapısal farklılıklar da doğrusal olmayan metotların kullanılmasıyla keşfedilebilecektir.

\section{Kaynaklar}

Abdioğlu, N. (2016). Corporate cash holdings and corporate governance quality in Turkey. International Journal of Management, Economics, and Business, ICAFR 16 Special Issue, 802-811.

Al-Najjar, B. (2013). The financial determinants of corporate cash holdings: Evidence from some emerging markets. International business review, 22(1), 77-88.

Amess, K., Banerji, S. ve Lampousis, A. (2015). Corporate cash holdings: Causes and consequences. International Review of Financial Analysis, 42, 421-433.

Arellano, M. ve Bond, S. (1991). Some tests of specification for panel data: Monte Carlo evidence and an application to employment equations. The Review of Economic Studies, 58(2), 277-297.

Arellano, M. ve Bover, O. (1995). Another look at the instrumental variable estimation of error-components models. Journal of Econometrics, 68(1), 29-51.

Bates, T. W., Kahle, K. M. ve Stulz, R. M. (2009). Why do US firms hold so much more cash than they used to? The Journal of Finance, 64(5), 19852021.

Bigelli, M. ve Sanchez-Vidal, J. (2012). Cash holdings in private firms. Journal of Banking \& Finance, 36(1), 26-35.

Brealey, R. A., Myers, S. C. ve Allen, F. (2011). Principles of Corporate Finance (10. ed.). Singapore: McGraw-Hill Irwin.

Brown, J. R. ve Petersen, B. C. (2011). Cash holdings and R\&D smoothing. Journal of Corporate Finance, 17(3), 694-709.

Demir, E. ve Ersan, O. (2017). Economic policy uncertainty and cash holdings: Evidence from BRIC countries. Emerging Markets Review, 33, 189-200.

Dittmar, A., Mahrt-Smith, J. ve Servaes, H. (2003). International corporate governance and corporate cash holdings. Journal of Financial and Quantitative Analysis, 38(1), 111-133.

Ferreira, M. A. ve Vilela, A. S. (2004). Why do firms hold cash? Evidence from EMU countries. European Financial Management, 10(2), 295-319.

Gao, H., Harford, J. ve Li, K. (2013). Determinants of corporate cash policy: Insights from private firms. Journal of Financial Economics, 109(3), 623-639. 
Nakit Tutma Oranının Finansal ve Kurumsal Belirleyicileri: Borsa İstanbul Üzerine Bir Inceleme

Garcia-Teruel, P. J. ve Martinez-Solano, P. (2008). On the determinants of SME cash holdings: Evidence from Spain. Journal of Business Finance \& Accounting, 35(1-2), 127-149.

Guizani, M. (2017). The financial determinants of corporate cash holdings in an oil rich country: Evidence from Kingdom of Saudi Arabia. Borsa Istanbul Review, 17(3), 133-143.

Hall, T., Mateus, C. ve Mateus, I. B. (2014). What determines cash holdings at privately held and publicly traded firms? Evidence from 20 emerging markets. International Review of Financial Analysis, 33, 104-116.

Jebran, K., Iqbal, A., Bhat, K. U., Khan, M. A. ve Hayat, M. (2019). Determinants of corporate cash holdings in tranquil and turbulent period: Evidence from an emerging economy. Financial Innovation, 5(1), 1-12.

Jensen, M. C. (1986). Agency cost of free cash flow, corporate finance, and takeovers. The American Economic Review, 76(2), 323-329.

Keynes, J. M. (1936). The general theory of employment, interest, and money. London: Macmillan.

Kusnadi, Y., Yang, Z. ve Zhou, Y. (2015). Institutional development, state ownership, and corporate cash holdings: Evidence from China. Journal of Business Research, 68(2), 351-359.

Kutlu Furtuna, Ö. (2017). Nakit bulundurma düzeyinin sektörel analizi: Borsa İstanbul'da işlem gören reel sektör firmaları üzerine bir uygulama. International Journal of Management, Economics, and Business, 13(3), 615-630.

Maddala, G. S. ve Wu, S. (1999). A comparative study of unit root tests with panel data and a new simple test. Oxford Bulletin of Economics and Statistics, 61(1), 631-652.

Myers, S. C. (1984). The capital structure puzzle. The Journal of Finance, 39(3), 574-592.

Myers, S. C. ve Majluf, N. S. (1984). Corporate financing and investment decisions when firms have information that investors do not have. Journal of Financial Economics, 13(2), 187-221.

Nickell, S. (1981). Biases in dynamic models with fixed effects. Econometrica: Journal of the Econometric Society, 49(6), 1417-1426.

Opler, T., Pinkowitz, L., Stulz, R. ve Williamson, R. (1999). The determinants and implications of corporate cash holdings. Journal of Financial Economics, 52(1), 3-46.

Orlova, S. V. ve Sun, L. (2018). Institutional determinants of cash holdings speed of adjustment. Global Finance Journal, 37, 123-137.

Özkan, A. ve Özkan, N. (2004). Corporate cash holdings: An empirical investigation of UK companies. Journal of Banking \& Finance, 28(9), 2103-2134. 
Pinkowitz, L. ve Williamson, R. (2001). Bank power and cash holdings: Evidence from Japan. The Review of Financial Studies, 14(4), 10591082.

Roodman, D. (2009). How to do xtabond2: An introduction to difference and system GMM in Stata. Stata Journal, 9(1), 86.

Uyar, A. ve Kuzey, C. (2014). Determinants of corporate cash holdings: Evidence from the emerging market of Turkey. Applied Economics, 46(9), 1035-1048.

Windmeijer, F. (2005). A finite sample correction for the variance of linear efficient two-step GMM estimators. Journal of Econometrics, 126(1), 2551 . 